\title{
Sistem Pakar Diagnosa Hipertiroid Menggunakan Certainty Factor dan Logika Fuzzy
}

\author{
Rizkita Apriliana ${ }^{1}$, Auli Damayanti² \& Asri Bekti Pratiwi ${ }^{3}$ \\ ${ }^{1,2,3}$ Departemen Matematika, Fakultas Sains dan Teknologi, Universitas Airlangga \\ ${ }^{2}$ Corresponding author: aulid@ fst.unair.ac.id
}

\begin{abstract}
Hyperthyroidism is a condition when the function of thyroid gland becomes excessive. The excess function of thyroid gland increases thyroid hormone production which affect body metabolism and physiological activity. This study aims to make an expert system diagnose hyperthyroidism with certainty factor and fuzzy logic. The stages of the process of diagnosing hyperthyroidism including problem identification, needs analysis of symptoms and types of hyperthyroidism, determination of rules, system design, case examples implementation, system testing, and evaluation. Variables used were systolic blood pressure, triiodothyronine (T3) levels, thyroxine (T4) levels, thyroid stimulating hormones (TSH) levels, goiter, tremors, and excessive sweating. All variables are processed using fuzzy logic with fuzzyfication stages, rule determination, min implications, max rule composition, and defuzzyfication which then proceed with certainty factor with sequential $\mathrm{CF}$ and $\mathrm{CF}$ stages. The system output is diagnosis the condition of hyperthyroidism such as hyperthyroidism, subclinical hyperthyroidism, and normal accompanied by a certainty factor. Based on the evaluation result, the accuracy of the expert system according to expert diagnostics is $86.7 \%$
\end{abstract}

Keywords: certainty factor, expert system, fuzzy logic, hyperthyroidism.

\section{Pendahuluan}

Hipertiroid adalah kondisi klinis yang disebabkan oleh peningkatan sintesis dan sekresi hormon oleh kelenjar tiroid yang mempengaruhi seluruh tubuh. Hipertiroid didefinisikan sebagai manifestasi klinis terkait dengan peningkatan hormon tiroid. Tanda-tanda dan gejala hipertiroid sangat beragam dan sebagian besar pengaruhi oleh usia pasien dan adanya gangguan pada organ tertentu. Gejala yang sering ditemui pada hipertiroid adalah kegelisahan, tremor, penurunan berat badan, palpitasi (dada berdebar), keringat berlebih. Sedangkan tanda klinis yang paling sering ditemui adalah struma kelenjar tiroid, fibrilasi atrium, hipertensi sistolik [1].

Penyakit hipertiroid adalah suatu keadaan ketika fungsi kelenjar tiroid menjadi berlebihan. Kelebihan fungsi kelenjar tersebut meningkatkan produksi hormon tiroid yang mempengaruhi metabolisme tubuh. Prevalensi hipertiroid di Indonesia berdasarkan wawancara yang terdiagnosis dokter sebesar $0,4 \%$ artinya lebih dari 700.000 penduduk 
Indonesia terdiagnosis hipertiroid [2]. Kelenjar tiroid menghasilkan hormon tiroid yaitu tiroksin (T4) dan triiodotironin (T3). Pembentukan hormon tiroid dipengaruhi oleh mekanisme umpan balik yang melibatkan hormon Thyroid Stimulating Hormon (TSH) [3]. Tubuh membutuhkan hormon tiroid sebagai pengendali pertumbuhan tubuh dan memproses metabolisme makanan menjadi energi. Kelenjar tiroid yang terlalu aktif atau yang disebut hipertiroid akan menyebabkan kadar hormon tiroid dalam darah sangat tinggi. Dalam dunia medis, untuk mendiagnosa penyakit hipertiroid sulit dilakukan karena gejala penyakit hipertiroid sangat bervariasi dan tergantung naik turunnya hormon tiroid [4]. Sehingga dibutuhkan suatu sistem yang dapat mempermudah proses diagnosa penyakit hipertiroid, salah satunya adalah sistem pakar.

Sistem pakar adalah suatu program komputer yang dirancang untuk memodelkan kemampuan penyelesaian masalah oleh pakar [5]. Sistem pakar sebagai kecerdasan buatan, menggabungkan pengetahuan dan fakta-fakta serta teknik penelusuran untuk memecahkan permasalahan yang secara normal memerlukan keahlian dari seorang pakar [6]. Dalam proses pengaplikasian sistem pakar terdapat fakta-fakta berupa gejala yang digunakan untuk diagnosa penyakit hipertiroid. Metode certainty factor merupakan metode yang mendefinisikan ukuran kepastian terhadap suatu fakta atau aturan untuk menggambarkan tingkat keyakinan pakar terhadap masalah yang sedang dihadapi. Dengan menggunakan Certainty factor ini dapat menggambarkan tingkat keyakinan pakar [7].

Dari berbagai macam gejala penyakit hipertiroid pada proses diagnosa penyakit akan muncul unsur ketidakpastian, sehingga dibutuhkan logika fuzzy dalam proses pengaplikasiannya. Logika fuzzy memiliki fleksibilitas yang tinggi sehingga dapat beradaptasi terhadap perubahan-perubahan yang terjadi dan ketidakpastian yang menyertai suatu permasalahan [8]. Berdasarkan uraian tersebut, sangat menarik untuk menggabungkan certainty factor dan logika fuzzy untuk mendiagnosa penyakit hipertiroid.

\section{$2 \quad$ Logika Fuzzy}

Teori himpunan fuzzy diperkenalkan pertama kali oleh Lotfi A. Zadeh pada tahun 1965. Logika Fuzzy dapat dianggap sebagai kontak hitam yang menghubungkan antara ruang input menuju ke ruang output. Kontak hitam tersebut berisi cara atau metode yang dapat digunakan untuk mengolah data input menjadi output dalam bentuk informasi yang baik [9].

\subsection{Himpunan Fuzzy}

Pada himpunan fuzzy nilai keanggotaan terletak pada rentang 0 sampai 1 . Terkadang kemiripan antara keanggotaan fuzzy dengan probabilitas menimbulkan kerancuan. Keduanya memiliki nilai pada interval $[0,1]$, namun interpretasi nilainya sangat berbeda 
antara dua kasus tersebut. Keanggotaan fuzzy memberikan suatu ukuran terhadap pendapat atau keputusan. sedangkan probabilitas mengindikasikan proporsi terhadap keseringan suatu hasil bernilai benar [8].

\subsection{Fungsi Keanggotaan}

Fungsi keanggotaan adalah suatu kurva yang menunjukkan pemetaan input data ke dalam nilai keanggotaannya (sering disebut dengan derajat keanggotaan) yang memiliki interval antara 0 sampai 1 . Salah satu cara yang dapat digunakan untuk mendapatkan nilai keanggotaan adalah dengan melalui pendekatan fungsi. Ada beberapa fungsi yang bisa digunakan [8]. Salah satu bentuk fungsi keanggotaan adalah representasi linier.

Pada representasi linear naik, kenaikan himpunan dimulai pada nilai domain yang memiliki derajat keanggotaan nol bergerak ke kanan menuju ke nilai domain yang memiliki derajat keanggotaan lebih tinggi [8]. Fungsi keanggotaan linear naik :

$$
\mu[x]=\left\{\begin{array}{cc}
0 ; & x \leq a \\
\frac{x-a}{b-a} & a \leq x \leq b \\
1: & x \geq b
\end{array}\right.
$$

Sedangkan pada representasi turun, garis lurus dimulai dari nilai domain dengan derajat keanggotaan tertinggi pada sisi kiri kemudian bergerak menurun ke nilai domain yang memiliki derajat keanggotaan lebih rendah [8]. Fungsi keanggotaan linear turun:

$$
\mu[x]=\left\{\begin{array}{rc}
1 ; & x \leq a \\
\frac{b-x}{b-a} ; & a \leq x \leq b \\
0 ; & x \geq b
\end{array}\right.
$$

\subsection{Fungsi Implementasi MIN}

Fungsi Implikasi MIN yaitu fungsi keanggotaan yang memotong output pada ketinggian fungsi yang disesuaikan dengan nilai premis untuk mengambil nilai keanggotaan terkecil antar elemen pada himpunan-himpunan yang bersangkutan [10]. Secara umum dirumuskan seperti berikut ini :

$$
\mu_{A \cap B}=\min \left(\mu_{A}(x), \mu_{B}(y)\right)
$$

\subsection{Komposisi Aturan MAX}

Komposisi adalah proses dimana himpunan fuzzy yang menyatakan output dari setiap aturan dikombinasikan bersama ke dalam sebuah himpunan fuzzy. Dalam komposisi MAX digunakan operator OR sehingga diperoleh nilai keanggotaan terbesar antar elemen pada semua himpunan fuzzy yang dihasilkan oleh proses inferensi untuk masing- masing aturan [10]. Secara umum dirumuskan seperti berikut ini : 


$$
\mu_{A \cup B}=\max \left(\mu_{A}(x), \mu_{B}(y)\right)
$$

\subsection{Defuzzyfication}

Setiap himpunan fuzzy dalam range tertentu, maka dapat diambil suatu nilai crips tertentu sebagai output. Pada Metode Centroid, solusi crips diperoleh dengan cara mengambil titik pusat $\left(\mathrm{z}^{*}\right)$ daerah fuzzy [8]. Secara umum dirumuskan dengan $z_{i}$ merupakan bobot pakar (i):

$$
Z *=\frac{\sum_{i=1}^{n} z_{i} \mu\left(z_{j}\right)}{\sum_{i=1}^{n} \mu\left(z_{j}\right)}
$$

\section{Certainty factor}

Certainty factor adalah suatu metode untuk membuktikan apakah suatu fakta itu pasti ataukah tidak pasti yang biasanya digunakan dalam sistem pakar. Certainty factor menyatakan kepercayaan dalam sebuah kejadian (fakta atau hipotesis) berdasarkan bukti atau penilaian dari seorang pakar [7]. Suatu aturan akan memiliki nilai certainty factor dari seorang pakar, sementara aturan tersebut juga memiliki certainty factor yang diperoleh dari premis-premis yang ada didalamnya (CF paralel), sehingga perlu dilakukan perhitungan nilai certainty factor untuk suatu aturan berdasarkan CF paralel dan CF yang diberikan oleh pengguna, yang disebut CF sequensial [11]. CF Sequensial diperoleh dari hasil perhitungan CF paralel dari semua premis dalam satu aturan dengan CF aturan yang diberikan oleh pakar. Adapun rumus untuk melakukan perhitungan CF Sequensial :

$$
C F(x, y)=C F(x) * C F(y)
$$

$C F(x, y):$ CFsequential of semua premis

$C F(x) \quad$ : CF paralel

$C F(y) \quad$ : CF pakar

$\mathrm{CF}$ gabungan merupakan $\mathrm{CF}$ akhir dari sebuah calon konklusi. $\mathrm{CF}$ ini dipengaruhi oleh semua CF paralel dari aturan yang menghasilkan konklusi tersebut. CF gabungan diperlukan jika suatu konklusi diperoleh dari beberapa aturan sekaligus. Adapun rumus untuk melakukan perhitungan CF gabungan [12]:

$$
\operatorname{CFCOMBINE}(C F 1, C F 2)=C F 1+C F 2 *(1-C F 1) \text { if } C F 1 \text { and } C F 2>0
$$

\section{Sistem Pakar}

Sistem pakar (expert system) adalah sistem yang berusaha mengadopsi pengetahuan pakar ke komputer, agar komputer dapat menyelesaikan masalah seperti yang biasa dilakukan oleh pakar. Dengan sistem pakar, orang awam dapat menyelesaikan masalah yang cukup rumit yang sebenarnya hanya dapat diselesaikan dengan bantuan para ahli. Bagi para ahli, 
sistem pakar juga akan membantu aktivitasnya sebagai asisten yang sangat berpengalaman [9]. Langkah-langkah pembuatan sistem pakar dengan menggunakan Certainty factor dan Logika Fuzzy untuk mendiagnosa hipertiroid dijelaskan sebagai berikut :

a) Proses Logika Fuzzy

Langkah 1: Menentukan input berupa nilai parameter yang diberikan responden.

Langkah 2: Menentukan derajat keanggotaan dengan langkah-langkah sebagai berikut:

i. Menentukan domain tiap himpunan fuzzy.

ii. Menentukan fungsi keanggotaan.

iii. Menentukan derajat keanggotaan.

Langkah 3: Menentukan aturan-aturan (rules) yaitu setiap premis dan konsekuen pada rule-rule dalam bentuk IF-THEN.

Langkah 4: Fungsi implikasi MIN

Langkah 5: Komposisi aturan MAX

Langkah 6: $\quad$ Defuzzifikasi

b) Proses Certainty factor

Langkah 1: Menentukan CF sequensial dari masing-masing aturan (rule) yang menunjukkan gejala-gejala pasien yang mengacu pada hipotesis yang sama.

Langkah 2: Menentukan nilai CF gabungan dari aturan-aturan (rules) yang mengacu pada hipotesis yang sama.

c) Menentukan jenis diagnosa Hipertiroid

\section{Pembahasan}

Berikut merupakan proses fuzzyfikasi dari setiap pertanyaan yang diajukan kepada pengguna :

1. Berapa tekanan darah sistolik anda ?

Tekanan darah sistolik normal memiliki kisaran $<120 \mathrm{mmHg}$ (Milimeter Hydrargyrum), sedangkan tekanan darah sistolik memiliki kisaran $>140 \mathrm{mmHg}$ (Milimeter Hydrargyrum) [2]. Pembentukan himpunan fuzzy dari pertanyaan tentang tekanan darah sistolik sesuai pada Tabel 1.

Tabel 1 Himpunan Fuzzy Tekanan Darah Sistolik

\begin{tabular}{|c|c|}
\hline Kondisi & Domain \\
\hline Normal & $x \leq 120$ \\
\hline Tinggi & $x \geq 140$ \\
\hline
\end{tabular}


Dari himpunan fuzzy diatas dibentuk fungsi keanggotaan serta representasi seperti pada Gambar 1.

$$
\begin{aligned}
& \mu_{\text {TDS Normal }}(x)=\left\{\begin{array}{cc}
1, \quad x \leq 120 \\
\frac{140-x}{140-120}, \quad 120 \leq x \leq 140 \\
0, \quad x \geq 140
\end{array}\right. \\
& \mu_{\text {TDS Tinggi }}(x)=\left\{\begin{array}{cc}
0, & x \leq 120 \\
\frac{x-120}{140-120}, & 120 \leq x \leq 140 \\
1, & x \geq 140
\end{array}\right.
\end{aligned}
$$

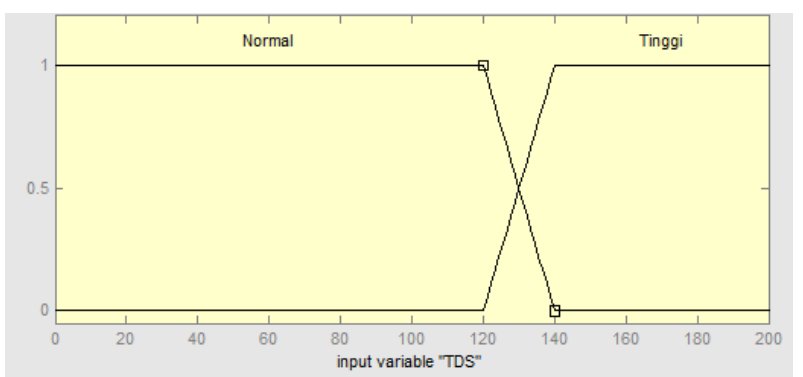

Gambar 1 Fungsi Keanggotaan Tekanan Darah Sistolik

2. Berapa hasil pemeriksaan triiodotironin (T3) anda?

Kadar triiodotironin (T3) normal pada manusia berkisar antara 0.6-1.85 ng/ml (Nanogram per Mililiter) [13]. Pembentukan himpunan fuzzy dari pertanyaan tentang pemeriksaan kadar triiodotironin (T3) sesuai pada Tabel 2.

Tabel 2 Himpunan Fuzzy T3

\begin{tabular}{|c|c|}
\hline Kondisi & Domain \\
\hline Normal & $x \leq 1.85$ \\
\hline Tinggi & $x \geq 2.02$ \\
\hline
\end{tabular}

Dari himpunan fuzzy diatas dibentuk fungsi keanggotaan serta representasi seperti pada Gambar 2.

$$
\mu_{\text {T3 Normal }}(x)=\left\{\begin{array}{cc}
1, \quad x \leq 1.85 \\
\frac{2.02-x}{2.02-1.85}, \quad 1.85 \leq x \leq 2.02 \\
0, \quad x \geq 2.02
\end{array}\right.
$$




$$
\mu_{\text {T3 Tinggi }}(x)=\left\{\begin{array}{cc}
0, & x \leq 1.85 \\
\frac{x-1.85}{2.02-1.85}, & 1.85 \leq x \leq 2.02 \\
1, & x \geq 2.02
\end{array}\right.
$$

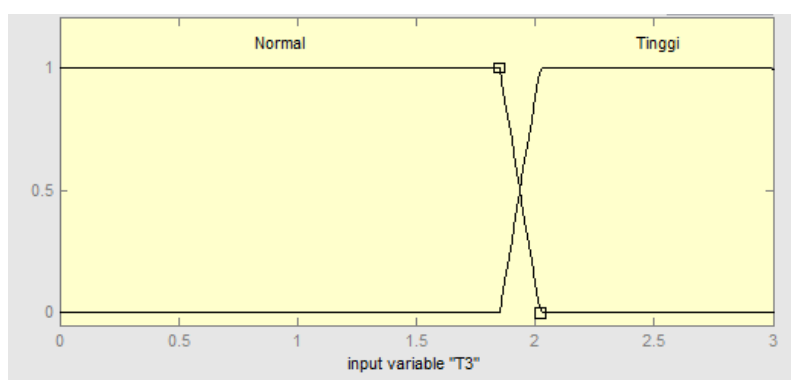

Gambar 2 Fungsi Keanggotaan Triiodotironin (T3)

3. Berapa hasil pemeriksaan tiroksin (T4) anda ?

Kadar Tiroksin (T4) normal berada pada kisaran 4.8-12 ng/dl (Nanogram per Deciliter) [14]. Pembentukan himpunan fuzzy dari pertanyaan tentang pemeriksaan kadar titoksin (T4) sesuai pada Tabel 3.

Tabel 3 Himpunan Fuzzy T4

\begin{tabular}{|c|c|}
\hline Kondisi & Domain \\
\hline Normal & $x \leq 12$ \\
\hline Tinggi & $x \geq 14.06$ \\
\hline
\end{tabular}

Dari himpunan fuzzy diatas dibentuk fungsi keanggotaan serta representasi seperti pada Gambar 3.

$$
\begin{aligned}
& \mu_{\text {T4 Normal }}(x)=\left\{\begin{array}{cc}
1, \quad x \leq 12 \\
\frac{14.06-x}{14.06-12}, 12 \leq x \leq 14.06 \\
0, x \geq 14.06
\end{array}\right. \\
& \mu_{\text {T4 Tinggi }}(x)=\left\{\begin{array}{cc}
0, & x \leq 12 \\
\frac{x-12}{14.06-12}, & 12 \leq x \leq 14.06 \\
1, & x \geq 14.06
\end{array}\right.
\end{aligned}
$$




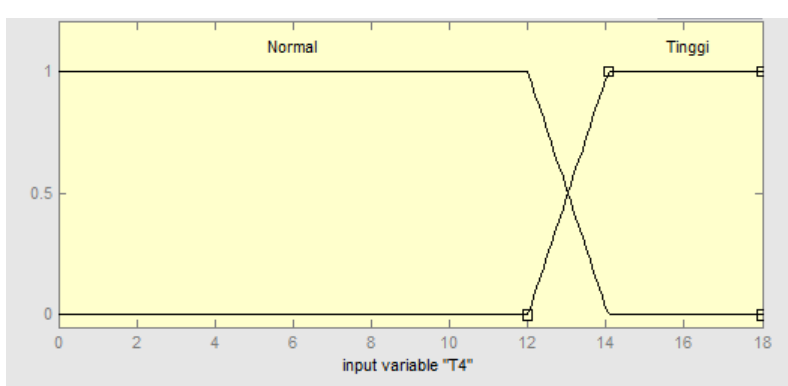

Gambar 3 Fungsi Keanggotaan Tiroksin (T4)

4. Berapa hasil pemeriksaan Thyroid Stimulating Hormon (TSH) anda ?

Kadar TSH $<0.4$ mU/L (Miliunit per Liter) mengindikasikan keadaan hipertiroid [15]. Pembentukan himpunan fuzzy dari pertanyaan tentang thyroid stimulating hormon $(\mathrm{TSH})$ sesuai pada Tabel 4.

Tabel 4 Himpunan Fuzzy TSH

\begin{tabular}{|c|c|}
\hline Kondisi & Domain \\
\hline Rendah & $x \leq 0.39$ \\
\hline Normal & $x \geq 0.4$ \\
\hline
\end{tabular}

Dari himpunan fuzzy diatas dibentuk fungsi keanggotaan serta representasi seperti pada Gambar 4.

$$
\begin{gathered}
\mu_{\text {TSH Rendah }}(x)=\left\{\begin{array}{cc}
1, \quad x \leq 0.39 \\
\frac{0.4-x}{0.4-0.39}, & 0.39 \leq x \leq 0.4 \\
0, & x \geq 0.4
\end{array}\right. \\
\mu_{\text {TSH Normal }}(x)=\left\{\begin{array}{cc}
0, & x \leq 0.39 \\
\frac{x-0.39}{0.4-0.39}, & 0.39 \leq x \leq 0.4 \\
1, & x \geq 0.4
\end{array}\right.
\end{gathered}
$$

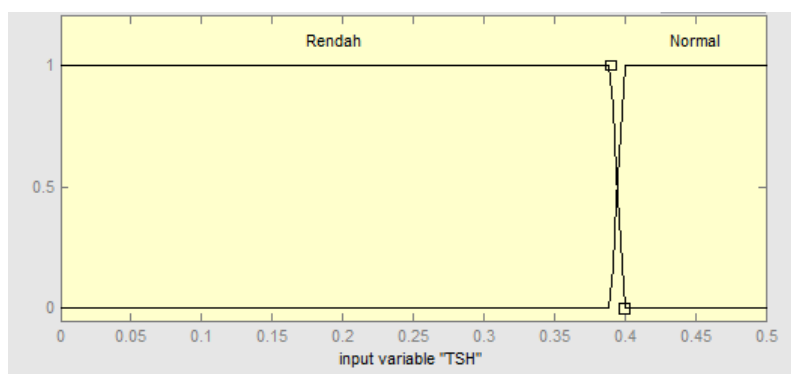

Gambar 4 Fungsi Keanggotaan Thyroid Stimulating Hormon (TSH) 
5. Apakah anda mengalami pembengkakan kelenjar tiroid?

Salah satu gejala sering ditemukan pada kasus hipertiroid adalah terjadinya pembengkakan kelenjar tiroid atau disebut dengan struma tiroid. Pembentukan himpunan fuzzy dari pertanyaan tentang pembengkakan kelenjar tiroid (struma tiroid) sesuai pada Tabel 5.

Tabel 5 Himpunan Fuzzy Struma Tiroid

\begin{tabular}{|c|c|}
\hline Kondisi & Derajat Keanggotaan \\
\hline Sangat yakin & 1 \\
\hline Yakin & 0.8 \\
\hline Cukup Yakin & 0.4 \\
\hline Tidak Yakin & 0.2 \\
\hline
\end{tabular}

6. Apakah anda mengalami tremor (gemetar)?

Selain adanya pembengkakan kelenjar tiroid, gejala lain yang sering ditemui adalah tremor atau gemetaran. Pembentukan himpunan fuzzy dari pertanyaan tentang tremor (gemetar) sesuai pada Tabel 6.

Tabel 6 Himpunan Fuzzy Tremor

\begin{tabular}{|c|c|}
\hline Kondisi & Derajat Keanggotaan \\
\hline Sangat Yakin & 1 \\
\hline Yakin & 0.8 \\
\hline
\end{tabular}

7. Apakah anda mengalami keringat berlebih di telapak tangan?

Hipertiroid juga disertai dengan gejala keringat yang berlebihan, salah satu yang sering ditemui adalah gejala keringat berlebihan ditelapak tangan. Pembentukan himpunan fuzzy dari pertanyaan tentang keringat berlebihan di telapak tangan sesuai pada Tabel 7.

Tabel 7 Himpunan Fuzzy Keringat Berlebih

\begin{tabular}{|c|c|}
\hline Kondisi & Derajat Keanggotaan \\
\hline Sangat Yakin & 1 \\
\hline Yakin & 0.8 \\
\hline Cukup Yakin & 0.4 \\
\hline Tidak Yakin & 0.2 \\
\hline
\end{tabular}

Kemudian dilanjutkan dengan perhitungan implikasi MIN, komposisi MAX dan defuzzyfikasi. Dan langkah terakhir adalah perhitungan $\mathrm{CF}$ sequensial dan $\mathrm{CF}$ gabungan. Berikut merupakan implementasi pada salah satu data pasien. 
Tabel 8 Data Pasien

\begin{tabular}{|c|l|c|}
\hline No. & \multicolumn{1}{|c|}{ Pertanyaan } & Input \\
\hline 1. & Berapa tekanan darah sistolik anda? & $130 \mathrm{mmHg}$ \\
\hline 2. & Berapa hasil pemeriksaan triiodotironin (T3) anda? & $1.92 \mathrm{ng} / \mathrm{ml}$ \\
\hline 3. & Berapa hasil pemeriksaan tiroksin (T4) anda? & $20.97 \mathrm{ng} / \mathrm{dl}$ \\
\hline 4. & $\begin{array}{l}\text { Berapa hasil pemeriksaan Thyroid Stimulating Hormon } \\
\text { (TSH) anda? }\end{array}$ & $0.398 \mathrm{mU} / \mathrm{L}$ \\
\hline 5. & Apakah anda mengalami pembengkakan kelenjar troid? & Yakin \\
\hline 6. & Apakah anda mengalami tremor (gemetar)? & Yakin \\
\hline 7. & $\begin{array}{l}\text { Apakah anda mengalami berkeringat dingin di telapak } \\
\text { tangan ? }\end{array}$ & Cukup Yakin \\
\hline
\end{tabular}

Berdasarkan Tabel 8 diperoleh himpunan fuzzy dan nilai keanggotaan dari setiap gejala seperti pada Tabel 9.

Tabel 9 Himpunan Fuzzy dan Nilai Keanggotaan

\begin{tabular}{|c|l|c|c|c|}
\hline No. & \multicolumn{1}{|c|}{ Parameter } & Nilai & Himp. Fuzzy & Derajat Keanggotaan \\
\hline \multirow{2}{*}{1.} & \multirow{2}{*}{ Tekanan Darah Sistolik } & \multirow{2}{*}{130} & Normal & 0.5 \\
\cline { 4 - 5 } 2. & \multirow{2}{*}{ T3 } & \multirow{2}{*}{1.92} & Tinggi & 0.5 \\
\cline { 4 - 5 } & & & Tinggi & 0.59 \\
\hline 3 & T4 & 20.97 & Tinggi & 0.41 \\
\hline 4 & TSH & \multirow{2}{*}{0.394} & Rendah & 0.6 \\
\cline { 4 - 5 } & & & Normal & 0.4 \\
\hline 5. & Struma Tiroid & 0.7 & Yakin & 0.8 \\
\hline & Tremor & 0.35 & Yakin & 0.8 \\
\hline 7 & Keringat Berlebihan & 0.35 & Cukup Yakin & 0.6 \\
\hline
\end{tabular}

Sehingga diperoleh aturan yang sesuai beserta bobot pakar seperti pada Tabel 10 . 
Tabel 10 Aturan yang sesuai

\begin{tabular}{|c|c|c|c|c|c|c|c|c|c|}
\hline Rule & TDS & T3 & T4 & TSH & ST & T & KB & keputusan & $\begin{array}{c}\text { Bobot } \\
\text { Pakar }\end{array}$ \\
\hline 234 & Normal & Normal & Tinggi & Rendah & Yakin & Yakin & $\begin{array}{c}\text { Cukup } \\
\text { Yakin }\end{array}$ & Hipertiroid & 0.54 \\
\hline Rule & TDS & T3 & T4 & TSH & ST & T & KB & Keptusan & Bobot \\
\hline 234 & 0.5 & 0.59 & 1 & 0.6 & 0.8 & 0.8 & 0.6 & Hipertiroid & 0.54 \\
\hline 490 & Normal & Tinggi & Tinggi & rendah & Yakin & Yakin & $\begin{array}{c}\text { Cukup } \\
\text { Yakin }\end{array}$ & Hipertiroid & 0.63 \\
\hline 490 & 0.5 & 0.41 & 1 & 0.6 & 0.8 & 0.8 & 0.6 & Hipertiroid & 0.63 \\
\hline 746 & Tinggi & Normal & Tinggi & Rendah & Yakin & Yakin & $\begin{array}{c}\text { Cukup } \\
\text { Yakin }\end{array}$ & Hipertiroid & 0.56 \\
\hline 746 & 0.5 & 0.59 & 1 & 0.6 & 0.8 & 0.8 & 0.6 & Hipertiroid & 0.56 \\
\hline 1002 & Tinggi & Tinggi & TIngi & Rendah & Yakin & Yakin & $\begin{array}{c}\text { Cukup } \\
\text { Yakin }\end{array}$ & Hipertiroid & 0.64 \\
\hline 1002 & 0.5 & 0.41 & 1 & 0.6 & 0.8 & 0.8 & 0.6 & Hipertiroid & 0.64 \\
\hline
\end{tabular}

Proses dilanjutkan dengan perhitungan implikasi MIN sehingga diperoleh hasil sebagai berikut:

$$
\begin{gathered}
\alpha_{\text {predikat-234 }}(z)=\min (0.5,0.59,1,0.6, \max (0.8,0.8,0.4))=0.5 \\
\alpha_{\text {predikat-490 }}(z)=\min (0.5,0.41,1,0.6, \max (0.8,0.8,0.4))=0.41 \\
\alpha_{\text {predikat-746 }}(z)=\min (0.5,0.59,1,0.6, \max (0.8,0.8,0.4))=0.5 \\
\alpha_{\text {predikat }-1002}(z)=\min (0.5,0.41,1,0.6, \max (0.8,0.8,0.4))=0.41
\end{gathered}
$$

Maka diperoleh komposisi aturan menggunakan metode MAX pada Tabel 11 berikut. 
Tabel 11 Komposisi Aturan

\begin{tabular}{|c|c|c|c|}
\hline $\begin{array}{c}\text { No. } \\
\text { rule }\end{array}$ & Keputusan & $\begin{array}{c}\text { Implikasi } \\
\text { MIN }\end{array}$ & Komposisi MAX \\
\hline 234 & Hipertiroid & 0.5 & \multirow{2}{*}{ Max $(0.5,0.41,0.5,0.41)=0,5$} \\
\hline 490 & Hipertiroid & 0.41 & \\
\hline 746 & Hipertiroid & 0.5 & \\
\hline 1002 & Hipertiroid & 0.41 & \\
\hline
\end{tabular}

Selanjutnya dilakukan perhitungan defuzzyfikasi yang kemudian digunakan sebagai nilai CF user.

$$
\begin{gathered}
z *=\frac{\left(w_{1} * z_{1}\right)+\left(w_{2} * z_{2}\right)+\left(w_{3} * z_{3}\right)+\left(w_{4} * z_{4}\right)}{w_{1}+w_{2}+w_{3}+w_{4}} \\
=\frac{(0.5 * 0.54)+(0.41 * 0.63)+(0.5 * 0.56)+(0.41 * 0.64)}{0.5+0.41+0.5+0.41} \\
=0.59
\end{gathered}
$$

Proses fuzzy selesai, kemudian dilanjutkan dengan perhitungan certainty factor. Proses diawali dengan perhitungan $\mathrm{CF}$ sequensial setiap aturan sehingga diperoleh hasil seperti pada Tabel 12.

Tabel 12 CF Sequensial

\begin{tabular}{|c|c|c|c|}
\hline No. Rule & CF $($ User $)$ & $\begin{array}{c}\text { CF } \\
(\text { Pakar })\end{array}$ & CF Sequensial = CF (User) * CF (Pakar) \\
\hline 234 & 0.59 & 0.54 & 0.32 \\
\hline 490 & 0.59 & 0.63 & 0.37 \\
\hline 746 & 0.59 & 0.56 & 0.33 \\
\hline 1002 & 0.59 & 0.64 & 0.38 \\
\hline
\end{tabular}

Berdasarkan CF Sequensial, maka diperoleh CF gabungan sebagai berikut:

$$
\begin{gathered}
C F\left(C F_{i}, C F_{i+1}\right)=C F_{i}+C F_{i+1}\left(1-C F_{i}\right) \\
C F_{x}\left(C F_{234}, C F_{490}\right)=C F_{234}+C F_{490}\left(1-C F_{234}\right) \\
C F_{x}=0.32+0.37(1-0.32)=0.57 \\
C F_{y}\left(C F_{x}, C F_{746}\right)=C F_{x}+C F_{746}\left(1-C F_{x}\right) \\
C F_{y}=0.5716+0.33(1-0.5716)=0.71 \\
C F_{z}\left(C F_{y}, C F_{1002}\right)=C F_{y}+C F_{1002}\left(1-C F_{y}\right) \\
C F_{z}=0.713+0.38(1-0.713)=0.82
\end{gathered}
$$

Berdasarkan hasil yang diperoleh maka sistem akan memberikan informasi bahwa pasien tersebut terindikasi hipertiroid dengan certainty factor $0.82 * 100 \%=82 \%$. 
Dengan cara yang sama, dilakukan perhitungan pada 15 data pasien diperoleh keputusan sistem dan faktor kepercayaan seperti pada Tabel 13.

Tabel 13 Hasil Keputusan Sistem

\begin{tabular}{|c|c|c|c|}
\hline \multirow{2}{*}{ No. Pasien } & \multirow{2}{*}{ Diagnosa pakar } & \multicolumn{2}{|c|}{ Diagnosa Sistem } \\
\cline { 3 - 4 } & & Keputusan & $\begin{array}{c}\text { Faktor } \\
\text { Kepercayaan }\end{array}$ \\
\cline { 3 - 4 } & & & $52 \%$ \\
\hline 1. & Normal & Normal & $81 \%$ \\
\hline 2. & Subklinis hipertiroid & Subklinis hipertiroid & $58 \%$ \\
\hline 3. & Hipertiroid & Hipertiroid & $67 \%$ \\
\hline 4. & Normal & Normal & $76 \%$ \\
\hline 5. & Subklinis hipertiroid & Subklinis hipertiroid & $31 \%$ \\
\hline 6. & Normal & Subklinis hipertiroid & $65 \%$ \\
\hline 7. & Hipertiroid & Hipertiroid & $54 \%$ \\
\hline 8. & Hipertiroid & Subklinis hipertiroid & $50 \%$ \\
\hline 9. & Subklinis hipertiroid & Subklinis hipertiroid & $52 \%$ \\
\hline 10. & Normal & Normal & $82 \%$ \\
\hline 11. & Hipertiroid & Hipertiroid & $75 \%$ \\
\hline 12. & Subklinis Hipertiroid & Subklinis hipertiroid & $59 \%$ \\
\hline 13. & Hipertiroid & Hipertiroid & $70 \%$ \\
\hline 14. & Normal & Normal & $86 \%$ \\
\hline 15. & Hipertiroid & Hipertiroid & \\
\hline
\end{tabular}

Berdasarkan hasil uji perbandingan yang ditunjukkan pada tabel diatas, dapat diketahui bahwa dari 15 data pasien terdapat 2 data pasien yang berbeda antara diagnosa pakar dengan diagnosa sistem. Sehingga dapat diperoleh besar prosentase kebenaran sistem dengan prosentase sebagai berikut:

$$
\begin{aligned}
\text { Recognition Rate }= & \frac{\text { benar }}{\text { jumlah data }} \times 100 \% \\
& =86.7 \%
\end{aligned}
$$

Jadi, prosentase akurasi sistem untuk diagnosa hipertiroid menggunakan certainty factor dan logika fuzzy sebesar $86.7 \%$.

\section{Kesimpulan}

Penerapan metode certainty factor dan logika fuzzy pada sistem pakar untuk mendiagnosa hipertiroid diawali dengan proses menggunakan logika fuzzy dan kemudian dilanjutkan menggunakan certainty factor. Berdasarkan hasil implementasi sistem pada contoh kasus menggunakan 15 data pasien dengan kondisi pasien yang heterogen, diperoleh output pada sistem berupa keputusan diagnosa hipertiroid pada 
masing-masing pasien beserta faktor kepercayaan. Berdasarkan hasil evaluasi, dapat disimpulkan bahwa terdapat beberapa perbedaan antara hasil diagnosa sistem dan diagnosa pakar dengan prosentase akurasi sistem sebesar $86,7 \%$.

\section{Daftar Pustaka}

[1] The Indonesian Soceiety of Endocrinology, 2012, Indonesian Clinical Practice Guidelines for Hyperthyroidism, Journal of the ASEAN Federation of Endocrine Societies (JAFES), Vol. 27 No. 1, Hal. 34-39.

[2] Kemenkes RI, 2013, Riset Kesehatan Dasar Riskesdas 2013, Jakarta.

[3] Kemenkes RI, 2015, Infodatin, Bebaskan Dirimu Dari Gangguan Tiroid, Jakarta.

[4] Rodiah, dan Widodo, R., 2015, Implementasi Fuzzy Inference System Sebagai Penunjang Diagnosis Hipertiroid, Seminar Nasional teknologi Informasi dan Komunikasi Terapan (SEMANTIK), Hal 471-476.

[5] Merlina, N., dan Hidayat, R., 2012, Perancangan Sistem Pakar; Studi Kasus; Sistem Pakar Kenaikan Jabatan, Ghalia Indonesia, Bogor.

[6] Desiani, A., dan Arhami., 2006, Konsep Kecerdasan Buatan, CV. ANDI OFFSET Yogyakarta, Yogyakarta

[7] Shortliffe, E., dan Buchanan, B., 1975, A Model of Inexact Reasoning Medicine, Mathematical Biosciences, 23:351-379.

[8] Kusumadewi, S., dan Purnomo, H., 2004, Aplikasi Logika Fuzzy untuk Pendukung Keputusan, Graha Ilmu, Yogyakarta.

[9] Kusumadewi, S., 2003, Artificial Intelligence (Teknik dan Aplikasinya), Graha Ilmu, Yogyakarta.

[10] Arhami, M., 2005, Konsep Dasar Sistem Pakar, CV. ANDI OFFSET Yogyakarta, Yogyakarta.

[11] Prihatini, P.M., 2011, Metode Ketidakpastian dan Kesamaran dalam Sistem Pakar, Lontar Komputer, Vol. 2 No. 1, 29-42.

[12] Kusrini, 2008, Aplikasi Sistem Pakar, C.V Andi Offset, Yogyakarta.

[13] Https://www.pointescientific.com/enzyme_immunoassay/product/137, 27 Juni 2019.

[14] Https://www.pointescientific.com/enzyme_immunoassay/product/139 , 27 Juni 2019.

[15] Kyrilli, A., Lytrivi, M., Lassen, P, B., Corvilain, B., 2018, Treatment options of subclinical hyperthyroidsm and cardiovascular risk, Current Opinion in endocrine and Metabolic Research. 